\title{
INCREASED HYDROPHOBICITY OF THE S' BINDING SITE IN CARBOXYPEPTIDASE Y OBTAINED BY SITE-DIRECTED MUTAGENESIS
}

\author{
by \\ JAKOB R. WINTHER, MORTEN C. KIELLAND-BRANDT ${ }^{1)}$ and KLAUS BREDDAM
}

\author{
Department of Chemistry, Carlsberg Laboratory, \\ Gamle Carlsberg Vej 10, DK-2500 Copenhagen Valby \\ "Department of Physiology, Carlsberg Laboratory, \\ Gamle Carlsberg Vej 10, DK-2500 Copenhagen Valby
}

Keywords: Carboxypeptidase $Y$, binding sites, protein engineering, site-directed mutagenesis, substrate specificity, oligonucleotide, chemical modification, kinetics, yeast

Chemical modification of Met-398 in carboxypeptidase $Y$ from yeast has previously been shown to affect the specificity of the enzyme with respect to the $\mathrm{P}_{1}^{\prime}$ position. To confirm and further study the role of Met-398, this residue was substituted by a leucyl residue by means of site-directed mutagenesis. The mutagenesis was carried out in bacteriophage M13 on a subcloned fragment of $P R C 1$, the structural gene for carboxypeptidase $\mathrm{Y}$, using a dodecanucleotide containing the desired mutation as primer for secondary strand synthesis in vitro. A clone was identified in which codon 398 of the carboxypeptidase $Y$ gene had been mutated from ATG to TTG while the rest of the subcloned region was conserved. This sequence was then reintroduced into the original $P R C I$ gene context and a $\Delta p r c l$ yeast strain was transformed with the resulting plasmid DNA.

The mutant enzyme, Leu-398-carboxypeptidase $Y$, was isolated by affinity chromatography and shown to have the same molecular weight, $\mathrm{N}$-terminal amino acid sequence and sugar content as carboxypeptidase $\mathrm{Y}$. Cyanogen bromide degradation confirmed the absence of Met-398.

Leu-398-CPD-Y was characterized kinetically using a series of $\mathrm{N}$-blocked dipeptide and ester substrates with varying groups in the $\mathrm{P}_{1}^{\prime}$ position. Compared with the wild type enzyme Leu-398-carboxypeptidase $\mathrm{Y}$ showed an increased affinity towards substrates with bulky and hydrophobic groups in the P' position. This is consistent with the leucyl side-chain being slightly smaller and more hydrophobic than the methionyl side-chain.

\footnotetext{
Abbreviations: $\mathrm{BCIG}=$ 5-bromo-4-chloro-3-indolyl- $\beta$-D-galactoside; $b p=$ base pairs; $\operatorname{cccDNA}=$ covalently closed circular DNA; CPD-Y = carboxypeptidase Y; DTT = dithiothreitol; EDTA = ethylenediamine tetraacetic acid; FA = furylacryloyl; gdDNA = gapped duplex DNA; Hepes = N-2-hydroxyethylpiperazin-N'-2-ethanesulfonic acid; IPTG = isopropyl- $\beta$-D-thiogalactoside; Leu-398-CPD-Y = CPD-Y with a leucyl residue at position 398; Mes = 2-(N-morpholino) ethanesulfonic acid; $\mathrm{RF}=$ replicative form; $\mathrm{SDS}=$ sodium dodecyl sulfate; $\mathrm{SSC}=0.15 \mathrm{M}-\mathrm{NaCl}$, $0.015 \mathrm{M}$-sodium citrate; ssDNA = single stranded DNA; Tris = tris(hydroxy methyl)aminomethane; The binding site notation is that of SCHECHTER and BERGER (25). Accordingly the binding site of the C-terminal amino acid of the substrate is denoted $S_{1}^{\prime}$ and those of the amino acid residues in the amino terminal direction away from the cleaved bond are denoted $S_{1}, S_{2}, \ldots, S_{n}$. In analogy to this the subtrate residues are denoted: $P_{1}^{\prime}$ and $P_{1}, P_{2}, \ldots, P_{n}$.
} 
J.R. WINTHER et al.: Mutagenesis on carboxypeptidase $\mathbf{Y}$

\section{INTRODUCTION}

Carboxypeptidase $\mathrm{Y}$ from yeast (CPD-Y) is the best characterized enzyme in the group of proteolytic enzymes termed "serine carboxypeptidases". The complete amino acid sequence is known (2) and the cloning of the $P R C l$ gene coding for CPD-Y from Saccharomyces cerevisiae has given access to the nucleotide sequence (Dr. T. STEVENS, personal communication).

The binding sites of CPD-Y have been investigated by means of chemical modifications producing active derivatives with altered substrate specificities $(3,4,5)$. Alkylations of methionine398 (Met-398), with e.g. phenacylbromide, resulted in a reduction in $\mathrm{k}_{\mathrm{cat}} / \mathrm{K}_{\mathrm{m}}$ for the hydrolysis of substrates with bulky leaving groups, i.e. amino acids and amino acid amides, and an increase in $\mathbf{k}_{\text {cat }} / \mathrm{K}_{\mathrm{m}}$ for those with non-bulky leaving groups, i.e. $-\mathrm{NH}_{2}$ and $-\mathrm{OCH}_{3}(3,4)$. Thus, the modified enzymes exhibit an altered specificity with respect to the $P_{1}^{\prime}$ position of all types of substrates (Figure 1), suggesting that Met-398 is located in or close to the $S_{1}$ binding site. The phenacylbromide modified enzyme has been shown to be useful as a deamidase in certain processes connected with enzymatic peptide synthesis (4).

It has recently become possible by genetic means to replace a particular amino acid residue with another residue through the use of site-directed mutagenesis $(9,10,27,28,30)$. The cloning of the PRCl gene made it feasible to investigate the significance of Met-398 in this fashion and in the present work it is demonstrated that the enzyme in which Met-398 has been replaced with a leucyl residue is active and exhibits catalytic properties that are consistent with the previous understanding of the location of Met-398.

\section{MATERIALS AND METHODS}

\subsection{Materials}

The plasmid pTSY3 containing the $P R C I$ gene coding for CPD-Y and the Saccharomyces cerevisiae strain SEY 2202 (MATa, $\Delta p r c 1$ $\Delta 1$ (LEU2), leu2-3, leu3-112, ura3-52, his4-519) was kindly provided by Dr. TOM STEVENS, Institute of Molecular Biology, University of Oregon, USA. Phage M13mp8 (21), Eschericia

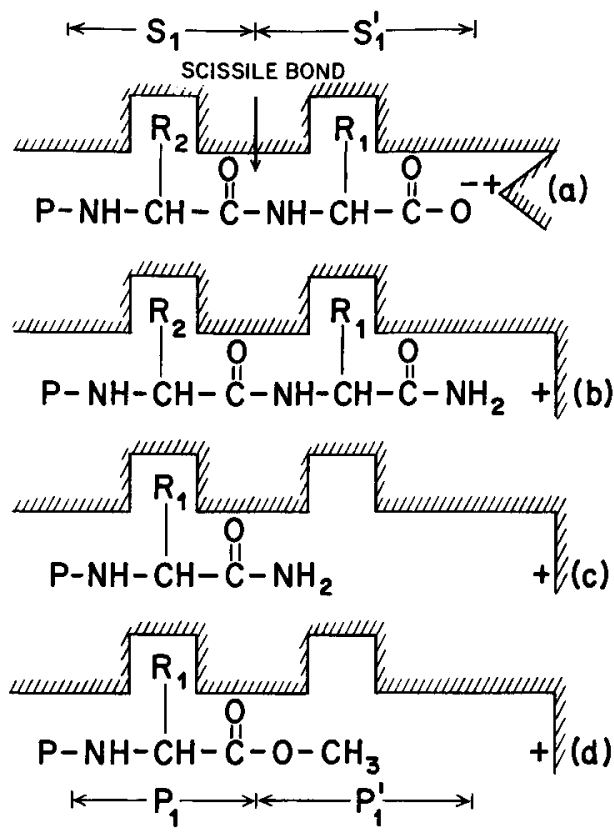

Figure 1. Schematic representation of the binding regions in the active site of CPD-Y, showing conceivable binding modes of peptides, peptide amides and peptide esters, which account for peptidase (a), peptidyl amino acid amide hydrolase (b), amidase (c) and esterase (d) activities of the enzyme. The binding site notation is that of SCHECHTER and BERGER as outlined in the abbreviations.

coli JM101 (19) and ED8654 (22) were from house collections.

Restriction endonucleases (EcoRI, BamHI, SalI, BglII, SmaI, PvuII), T4 DNA ligase, DNA polymerase I (Klenow fragment), calf intestine phosphatase, T4 polynucleotide kinase, 2'-deoxyribonucleotide triphosphates, adenosine triphosphate, M13 sequencing primer 5'd(TCCCAGTCACGACTG)-3', BCIG and IPTG were obtained from Boehringer Mannheim, FRG. 2',3'-dideoxyribonucleotide triphosphates were obtained from P-L Biochemicals, USA. $\left[\alpha-{ }^{32} \mathrm{P}\right] \mathrm{dATP}(>800 \mathrm{Ci} / \mathrm{mmol})$ and $\left[\gamma_{-}{ }^{32} \mathrm{P}\right] \mathrm{ATP}(>7000 \mathrm{Ci} / \mathrm{mmol})$ were from New England Nuclear, USA, and the synthetic oligonucleotide 5'-d(CCACTTGGTTCC)-3' was from Amersham International, UK. Low Melting Point Agarose was obtained from Bethesda Research Laboratories, USA. Nitrocellu- 
lose filters were from Schleicher \& Schuell, FRG. Biogel P-60 from Biorad, USA. Trizma base, Mes, Hepes, DTT and agarose were from Sigma, USA. All other chemicals and solvents were of analytical grade.

The following compounds were synthesized as previously dèscribed (4): FA-Phe-Gly-OH, FA-Phe-Ala-OH, FA-Phe-Val-OH, FA-PheLeu-OH, FA-Phe-Phe-OH, FA-Ala-OBzl, FAPhe-OEt, FA-Ala-Phe-OH, FA-Val-Phe-OH, FA-Ala-O'Bu, FA-Ala-OEt.

Programs for handling of DNA sequence material was kindly supplied by Dr. R. STADEN, MRC, Cambridge, UK.

\subsection{Methods}

\subsubsection{Cloning procedures}

The following procedures were carried out as outlined by MANIATIS et al. (17): Restriction endonuclease digestions, formation of blunt ends from recessed 3'-ends with the Klenow fragment of DNA polymerase I, phosphatase treatment and ligation of double stranded DNA fragments. Transformation of E. coli strains (JM101 and ED 8654) was performed using 50 $\mathrm{mM}^{-} \mathrm{CaCl}_{2}(16)$ while yeast strain SEY 2202 was transformed by the alkali ion method (12) using $\mathrm{LiNO}_{3}$. Propagation, harvesting and screening of $\mathrm{M} 13$ recombinants as well as preparation of ssDNA and chain termination sequencing were carried out as described $(20,24)$. Plasmids and RF-DNA of bacteriophage M13 derivatives were isolated by the rapid boiling method (11) for analytical purposes and by the alkaline lysis method (1) for preparative purposes. DNA from preparative agarose gel electrophoresis was isolated from low melting temperature agarose by extraction with phenol and chloroform (17) or by electrophoresis onto a dialysis membrane (29). Synthetic media for yeast were prepared as described by PETERSEN et al. (23).

\subsubsection{Subcloning of the $620 \mathrm{bp} \mathrm{BglII-PvuII}$ fragment of pTSY3 into $M 13 \mathrm{mp} 8$}

The pTSY 3 plasmid contains the total coding region of CPD-Y cloned in the YEp24 (6) yeast/E. coli shuttle vector. The $303 \mathrm{C}$-terminal bp of the coding region is situated on a $620 \mathrm{bp}$
BglII-Pvull fragment where the codon for Met398 is found 229 bp downstream of the Bglll site. The BglII-Pvull fragment was cloned into M13mp8 in the following way: M13mp8 RF DNA was digested with SmaI and SalI and the recessed ends of the SalI site were converted into blunt ends using DNA polymerase I, Klenow fragment. The $620 \mathrm{bp}$ fragment was prepared by digestion of pTSY3 with BglII and PvuII followed by formation of blunt ends at the BglII site as described above. DNA from the two digestion mixtures were then mixed in a fragment to vector ratio of 3 and ligated with T4 DNA ligase. The DNA was used to transfect competent cells of E.coli JM101 which were subsequently plated in soft agar in the presence of $0.5 \mathrm{mM}$-IPTG and $0.03 \% \mathrm{BCIG}$. White plaques were screened for the presence of an insert with the BglII site of the $620 \mathrm{bp}$ fragment intact and situated adjacent to the site of the M1 3 universal sequencing primer. Sequencing was utilized for final identification of the desired recombinant which was designated G42.

\subsubsection{In vitro mutagenesis}

In order to replace Met-398 in CPD-Y with a leucyl residue an oligonucleotide with the sequence 5'-d(CCACTTGGTTCC)-3' was chosen. This nucleotide contains the desired base substitution and a DNA window search program had shown that hybridization to other sites in G42 than the one intended was not probable. Priming specificity of the oligonucleotide was tested by primer extension followed by restriction enzyme digestion essentially as described by ZOLLER and SMITH (30).

Phosphorylation of the oligonucleotide was carried out using the method of MAXAM and GilberT (18).

Using 1 pmol G42 and 20 pmol phosphorylated primer the mutagenesis experiment was carried out as described by ZOLLER and SMITH (30) with the exception that only unlabelled dATP was used for secondary strand synthesis and electrophoresis was employed for cccDNA purification. Thus, following extention and ligation by DNA polymerase I (Klenow fragment) and T4 DNA ligase for $20 \mathrm{~h}$ at $15^{\circ} \mathrm{C}$ the total reaction mixture was subjected to electropho- 
resis on a $0.7 \%$ low melting temperature agarose gel for $2 \frac{1}{2} \mathrm{~h}$ at $3 \mathrm{~V} / \mathrm{cm}$ in a buffer containing 2 $\mu \mathrm{g} / \mathrm{ml}$ ethidium bromide, $40 \mathrm{mM}$-Tris, $20 \mathrm{~mm}$ acetic acid, 2 mM-EDTA, pH 8.5. At the concentrations of ethidium bromide used it was required that DNA was loaded without the bromophenol blue marker, since this causes precipitation of the DNA-bound ethidium ions. To prevent nicking of the cccDNA the electrophoresis was performed in the dark and the band containing cccDNA was excised under UV illumination and used for the transfection of JM101.

The resulting phage progeny was screened for mutants using the ${ }^{32} \mathrm{P}$-labelled mutagenic oligonucleotide as hybridization probe in the following way: Phages were propagated from 19 individual plaques, ssDNA purified from the phage particles and approximately $0.5 \mu \mathrm{g}$ of ssDNA from each preparation was spotted onto dry nitrocellulose filter paper. After incubation at 80 ${ }^{\circ} \mathrm{C}$ for $18 \mathrm{~h}$ the filter was pretreated with $6 \times \mathrm{SSC}$, $10 \times$ Denhardts solution $(0.2 \%$ bovine serum albumin, $0.2 \%$ poly(vinylpyrrolidone), $0.2 \% \mathrm{Fi}$ coll) (7), $0.2 \%$ SDS at $65^{\circ} \mathrm{C}$ for $1 \mathrm{~h}$. Hybridization was performed at $10{ }^{\circ} \mathrm{C}$ in $6 \times \mathrm{SSC}$, $10 \times$ Denhardts for $1 \mathrm{~h}$ and the filter was then washed at the same temperature for 15 minutes in $6 \times \mathrm{SSC}$ and exposed to X-ray film. Similar washes in $6 \times \mathrm{SSC}$ at $20^{\circ} \mathrm{C}$ and $30^{\circ} \mathrm{C}$ were carried out and the hybridization signal followed by autoradiography.

A phage DNA preparation showing stronger hybridization signal than the G42 control DNA was subjected to two successive rounds of plaque purification and five of the resulting clones were sequenced for confirmation of their mutant identity. From one of them, K6-6, the mutated sequence was reintroduced into the original $P R C 1$ gene context as described below.

\subsubsection{Introduction of the Leu-398 mutation in pTSY3}

The M13mp8 vector contains one BglII and three PvuII sites and digestion of M13mp8 with these enzymes produces four DNA fragments of $93,301,560$ and $6851 \mathrm{bp}$, respectively. In the construction of the G42 phage a new BgllI site was introduced and thus, digestion of K6-6
RF-DNA with BgllI and Pvull produced five fragments of the sizes: 93, 107, 560, 800 and $6851 \mathrm{bp}$, respectively. These fragments were separated by electrophoresis on a $2.0 \%$ preparative agarose gel and the $800 \mathrm{bp}$ fragment was recovered. This fragment contained the $620 \mathrm{bp}$ subcloned region of $P R C 1$ in addition to $180 \mathrm{bp}$ of the M13mp8 encoded lacZ gene. pTSY3 was similarly digested with BglII and PvuII and subsequently treated with calf intestine phosphatase to reduce the number of self ligation events. The two DNA species were ligated and used for transformation of ED8654. The resulting recombinants were identified by EcoRI digestion, since the inserted fragment contained an EcoRI site which was not present in the original pTSY3. A plasmid, pL7, with the desired configuration was propagated and the presence of the mutation was confirmed by sequencing of the $\mathrm{C}$-terminal part of the coding region in an appropriate fragment subcloned in M13mp8. The plasmids pL7 and pTSY3 were introduced into S. cerevisiae SEY 2202 and plasmid bearing cells were grown to saturation under aerobic conditions on a complete synthetic medium free of uracil.

\subsubsection{Isolation and characterization of Leu- 398-CPD-Y}

Leu-398-CPD-Y was purified by affinity chromatography as described for wild type CPD-Y (13), and the purity of the resulting enzyme was ascertained by SDS-polyacrylamide gel electrophoresis on $1 \mathrm{~mm}$ thick $7.5 \%$ gel slabs in an SDS-phosphate continuous buffer system (26). The enzyme was identified as a CPD-Y derivative by $\mathrm{N}$-terminal amino acid sequencing using a Beckman $890 \mathrm{C}$ liquid phase sequencer and the approximate carbohydrate content was estimated by means of the phenolsulfuric acid method of DuBoIs (8), using glucose as standard. Cyanogen bromide cleavage of Leu-398CPD-Y and separation of the resulting peptides were performed as previously described (2).

\subsubsection{Determination of kinetic constants and thermostability}

The kinetic constants for the hydrolysis of 
various FA- peptide and ester substrates by Leu-398-CPD-Y and the CPD-Y encoded by the wild type plasmid were determined from Lineweaver-Burk plots. Hydrolysis rates were determined spectrophotometrically at $25^{\circ} \mathrm{C}$ and at wavelengths of $329-358 \mathrm{~nm}$, depending on substrate concentration. Peptide substrates were assayed in $50 \mathrm{~mm}$-Mes, $1 \mathrm{mM}$-EDTA, pH 6.5 whereas ester substrates were assayed in 50 mM-Hepes, 1 mM-EDTA, pH 7.5. Determinations of $k_{\text {cat }}$ and $K_{m}$ for the hydrolysis of FA-Phe-Phe-OH and FA-Val-Phe-OH were not possible at $\mathrm{pH} 6.5$ because of the low value of $\mathrm{K}_{\mathrm{m}}$; the activities of the two enzymes towards these substrates were measured at $\mathrm{pH} 7.2$ in a 50 mM-Hepes buffer.

The relative stabilities of CPD-Y and Leu398-CPD-Y were measured by incubation of the enzymes in $50 \mathrm{~mm}$-Mes, $1 \mathrm{mM}-\mathrm{mDTA}$, pH 6.5 at $55^{\circ} \mathrm{C}$ using a concentration of $0.1 \mathrm{mg} / \mathrm{ml}$. The activity towards FA-Phe-Leu-OH was followed as a function of time and the assays were performed in the same buffer as the incubation.

\section{RESULTS AND DISCUSSION}

Chemical modifications of Met-398 in carboxypeptidase $\mathrm{Y}$ have demonstrated that various bulky groups (e.g. p-nitrophenacyl) can be attached to this amino acid residue without seriously reducing the stability of the enzyme. However, this need not indicate that the enzyme would attain the proper tertiary structure if, for instance, Met-398 was exchanged with a charged amino acid by site-directed mutagenesis, prior to folding of the enzyme. To meet these concerns it was decided to induce a conservative change, sterically as well as chargewise, altering Met-398 to a leucyl residue.

Two items were essential to conduct this experiment: A plasmid containing the $P R C I$ gene and an oligonucleotide containing the desired mutation. The design and properties of the oligonucleotide will be discussed later. The plasmid used in the present work, pTSY3, contained a 3200 bp fragment of the yeast chromosome inserted in the Sall and PvulI sites of the yeast/E. coli shuttle vector, YEp24 (6) (Figure 2). The translation of $P R C l$ starts about $1300 \mathrm{bp}$ from the Sall site and extends 1596 bp towards the Pvull site. In addition to the unique SalI and PvuII sites a single BglII site is situated about $620 \mathrm{bp}$ from the PvulI site in the $P R C 1$ coding region. To perform the site-directed mutagenesis converting CPD-Y into Leu-398-CPD.Y it was necessary to subclone the part of the gene containing the target codon into an M13 phage derivative, preferentially in a manner which allowed subsequent sequencing of the total subcloned region by dideoxy-sequencing using the universal sequencing primer. It was furthermore necessary to construct this subclone in such a way that the subcloned fragment could be reinserted correctly into pTSY3 after the mutagenesis had been performed. These requirements were fulfilled by the $620 \mathrm{bp} \mathrm{BgllI-}$ PvulI fragment which contained the Met-398 codon situated in a 303 bp C-terminal portion of the coding region. Since no $\mathrm{M} 13 \mathrm{mp}$ derivative contains a BglII site in the polylinker region the following scheme for subcloning was undertaken (see Figure 2): M13mp8 RF DNA was digested with Sall and Smal and the recessed 3' end of the Sall site was extended to flush with the 5' end using DNA polymerase I, Klenow fragment. In the same fashion pTSY3 was digested with BglII and PvuII and the BgIII site was filled up. In the subsequent ligation reaction insertion of the BglII-Pvull fragment could take place in two orientations, of which only the one where the filled up Sall and BgllI ends met would result in the reestablishment of the Bglll site. After ligation and transformation of E. coli JM101 an M13mp8 recombinant (designated G42) was identified which contained an intact Bglll site and in which it was possible to sequence the total subcloned coding region.

Substitution of Met-398 with a leucyl residue involved only a single base pair mutation from ATG to TTG. TTG was preferred to CTG since it would be possible in the future to obtain a TGG codon for tryptophan by a single base pair mutation. The oligonucleotide used to obtain this mutation had to meet two requirements: A high degree of specificity for base pairing at the Met-398 site of the G42 ssDNA template (Figure 3 ) and the ability to function as primer for DNA polymerase I (Klenow fragment) at 
Figure 2. Construction of the PRC1-M13-subclone: G42

\section{M13mp8}

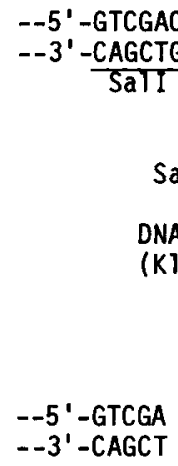

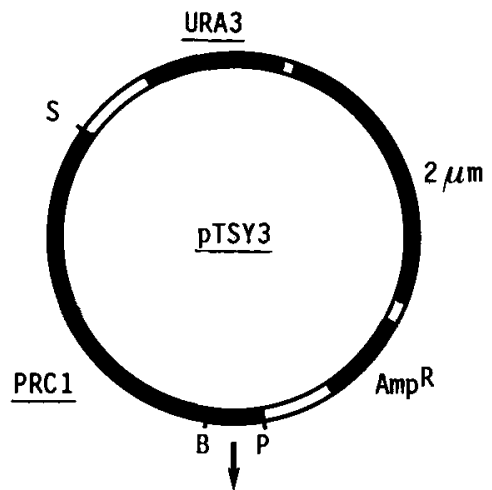

- $5^{\prime}$-AGATCT-----CAGCTG-3' --

--3' -TCTAGA-----GTCGAC-5' -BgIII PVUII

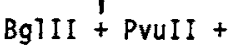
I

DNA polymerase I (Klenow fragment)<smiles>CCCCC</smiles><smiles>CC(C)[Al][Ge]</smiles><smiles>[Mg][GeH2][GeH2]</smiles>
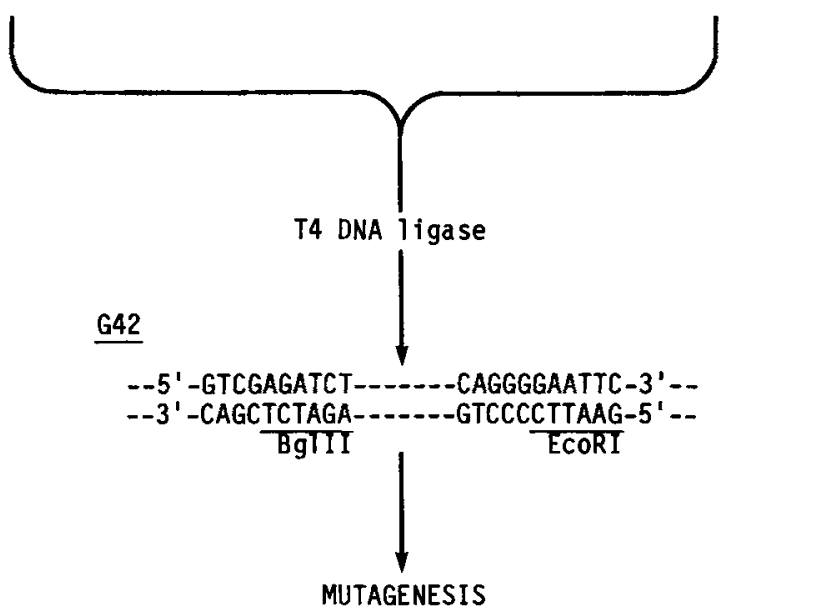

The BglII-PvuII fragment containing the C-terminal part of the $P R C 1$ coding region was subcloned into M13mp8 in the following way: The polylinker region of M $13 \mathrm{mp} 8$ was digested with Sall and SmaI while pTSY3 was digested with BglII and PvuII. Recessed 3' ends were filled up with the large fragment of DNA polymerase I and upon ligation a recombinant (G42) containing a restored BgllI site was isolated and subjected to mutagenesis (Figures 3 and 4).

Abbreviations for restriction sites: $\mathrm{B}=$ BglII; $\mathbf{P}=$ Pvull; $\mathrm{S}=$ Sall. 
Mutant sequence:

Mutagen 1c oligonucleotide: G42 template:

Wild-type sequence: Amino acid positions:

Figure 3. The mutagenic oligonucleotide forms a mismatch-containing duplex with a strech of the G42 template surrounding the codon 398 in the CPD-Y amino acid sequence.

this site. In the design of such an oligonuclotide different sequences coding for this mutation were surveyed for alternative sites of hybridization on the G42 template. A computerized screening showed that it was not probable that an oligonucleotide with the sequence 5'-d(CCACTTGGTTCC)-3' would hybridize at other positions than the desired one. This specificity was ascertained experimentally by the method of primer extention followed by restriction endonuclease digestion (30). With this test no alternative priming sites could be detected within the subcloned region at various primer to template ratios and annealing temperatures.

The mutagenesis experiment was performed essentially as described by ZOLLER and SMITH (30) (Figure 4): The oligonucleotide was hybridized to the G42 template and extended using the Klenow fragment of DNA polymerase I for $20 \mathrm{~h}$ at $15^{\circ} \mathrm{C}$ in the presence of T4 DNA ligase. The total reaction mixture was then subjected to agarose gel electrophoresis in the presence of ethidium bromide. This procedure allowed good separation of the three major DNA components in the reaction mixture, i.e. ssDNA, cccDNA and gdDNA. The cccDNA, identified as the band migrating with the same velocity as G42-RF DNA, was excised from the gel, and used for the transformation of $\mathrm{E}$. coli JM101.

The resulting phage progeny may contain either the complement to the ATG methionine codon or the complement to the chemically synthesized TTG leucine codon at the site of the original heteroduplex. Theoretically, half the progeny should be of the mutant type, but this is hardly ever obtained, probably due to the absence of adenine methylation at GATC-sites on the in vitro synthesized strand (14). The mutants were distinguished from wild type phage by utilizing the fact that the mutagenic primer exhibited a tighter binding to the mutant ssDNA than to wild type ssDNA, since the duplex formed by the latter contained a mismatch.

In the present experiment the strength of the hybridization of the mutant DNA could be clearly distinguished from the G42 wild type control after a wash at $30^{\circ} \mathrm{C}$ (Figure 5). Although the potential mutant phage stock was grown from a single plaque it could still contain a mixture of wild type and mutant phages due to the heteroduplex nature of the transforming DNA, and it was therefore necessary to ensure a pure clone by plaque purification (20). DNA sequencing of a clone, designated K6-6, confirmed the ATG to TTG mutation (Figure 6) and the absence of other mutations unintendedly introduced in the subcloned coding region of $P R C 1$.

Digestion of K6-6 RF-DNA with BgIII and PvulI produced four fragments, one of which contained the complete K6-6 subcloned DNA from the original pTSY 3 and 178 bp of the lac $Z$ gene. This fragment of $800 \mathrm{bp}$ was purified and ligated into BglII-PvulI digested and phosphatase treated pTSY3. The recombinants could be identified by the appearance of a new EcoRI site and sequencing of one of these clones, pL7, confirmed the insertion of the mutated gene fragment.

In order to produce the Leu-398-CPD-Y free from wild type enzyme S. cerevisiae strain SEY 2202 was transformed with pL7. SEY 2202 contains a deletion in the $P R C 1$ chromosomal gene in addition to the ura3-52 mutation necessary for plasmid selection. A culture of SEY 2202 containing the pL7 plasmid was grown to stationary phase in synthetic complete medium devoid of uracil. From $180 \mathrm{~g}$ of these cells about $25 \mathrm{mg}$ of Leu-398-CPD-Y was purified by affinity chromatography with a yield of $80 \%$. The enzyme was shown to be homogeneous by SDS gel electrophoresis and by its elution as a single symmetrical peak from a DEAE-Sephacel column. The molecular weight, sugar content and $\mathrm{N}$-terminal sequence 

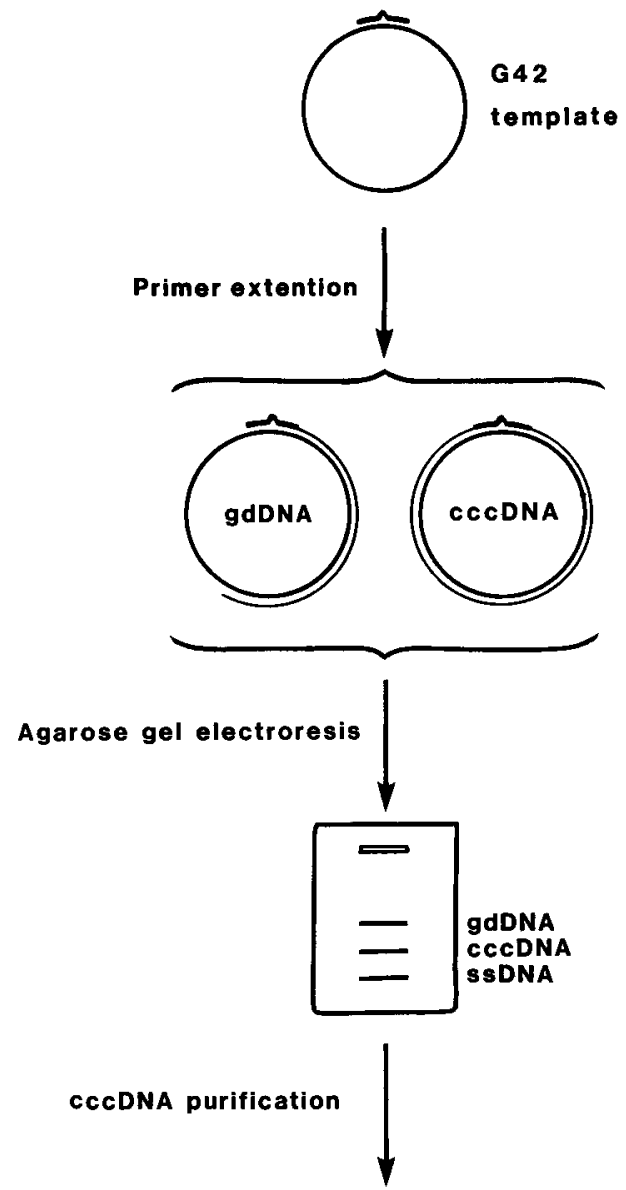

were in accordance with the results previously obtained with CPD-Y (13).

In order to confirm the presence of a leucyl residue at position 398 Leu-398-CPD-Y was cleaved at the methionyl residues with cyanogen bromide. With unmodified enzyme, this treatment resulted in six fragments: 1-191, 192210, 211-313, 314-398, 399-410 and 411-421 (2). In the absence of Met-398 the peptide 314-410 would be produced instead of the two peptides 314-398 and 399-410. After separation of the produced peptides into three fractions by gel filtration on a Biogel P-60 column the fraction normally containing only the peptide 314-398 was subjected to amino acid analysis. The result of this analysis was consistent with that of peptide $314-410$ but not with that of 314-398, confirming that position 398 was not occupied by a methionyl residue. This conclusion was also supported by the absence of an effect of phenacylbromide on the activities of Leu-398-CPD-Y. With CPD-Y this treatment results in a drastic reduction of the activity towards FA-Phe-Leu-OH and an increase in that towards FA-Phe-OMe (4). Thus, Met-398 is indeed the site of reaction of phenacylbromide on normal CPD-Y.

Chemical modification of Met-398 has previously been shown to affect the specificity of CPD-Y (4) and consequently, purified Leu398-CPD-Y was kinetically characterized, using a series of FA-ester and peptide substrates with different leaving groups. The kinetic parameters for CPD-Y (4) and Leu-398-CPD-Y are listed

Figure 4. Mutagenesis.

The mutagenic oligonucleotide is hybridized onto the G42 template at the site to be mutated (Figure 3) where it acts as a primer for DNA polymerase I (Klenow fragment) and the resulting double stranded DNA circles are closed covalently using T4 DNA ligase. Molecules containing single stranded regions (gdDNA) can transfect $E$. coli but the frequency of mutants is much lower in this class (10). Consequently cccDNA is purified and used to transform E. coli JM101. Replication of the heteroduplex DNA gives rise to mutant and wild type progeny which are distinguished by hybridization (Figure 5). 


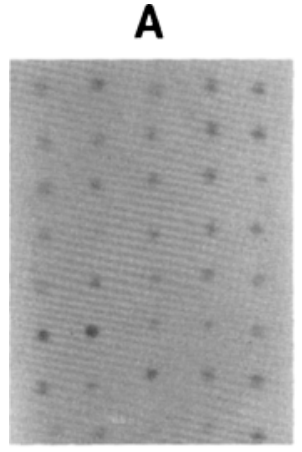

$10^{\circ} \mathrm{C}$

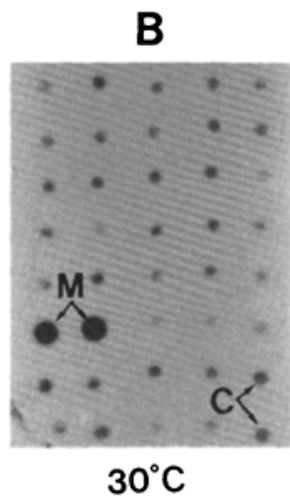

Figure 5. Hybridization screening for Leu-398 mutants using the ${ }^{32} \mathrm{P}$-labelled mutagenic oligonucleotide. Preparations of ssDNA from 19 plaques from the mutagenesis were spotted in duplicate onto dry nitrocellulose and hybridized with the ${ }^{32} \mathrm{P}$-labelled mutagenic dodecanucleotide. Autoradiograph A was taken after the initial wash at $10^{\circ} \mathrm{C}$ in $6 \times S S C$ for 10 minutes. Autoradiograph $B$ was taken after a wash at $30^{\circ} \mathrm{C}$ in $6 \times \mathrm{SSC}$ for 20 minutes and the mutant $(\mathrm{M})$ is here clearly distinguished from the G42 control (C).

in Table I. Compared with CPD-Y, Leu-398CPD-Y generally exhibits reduced $k_{\text {cat }}$ values for the hydrolysis of peptide and ester substrates, whereas $\mathrm{K}_{\mathrm{m}}$ is affected in a way that is dependent on the group occupying the $P_{i}^{\prime}$ position. For the peptide substrates FA-Phe-Gly-OH and FAPhe-Ala-OH and the ester substrate FA-AlaOEt, which all are characterized by relatively small groups at the $\mathrm{P}_{\text {i position, }} \mathrm{K}_{\mathrm{m}}$ is increased, while for FA-Phe-Leu-OH, FA-Phe-Phe-OH, FA-Ala-O'Bu and FA-Ala-OBzl, all characterized by bulky and strongly hydrophobic leaving groups, $\mathrm{K}_{\mathrm{m}}$ is decreased. This effect is also reflected in the $k_{c a} / K_{m}$ values, since Leu398-CPD- $Y$ exhibits decreased $k_{\text {cal }} / K_{m}$ values towards substrates with small leaving groups, and increased values for the substrates with large leaving groups.

The increased preference for Phe in the $\mathrm{P}_{1}$ position is essentially independent of the amino acid residue occupying the $P_{1}$ position since $\mathrm{k}_{\mathrm{cat}} / \mathrm{K}_{\mathrm{m}}$ for the hydrolysis of FA-Phe-Phe-OH, FA-Val-Phe-OH and FA-Ala-Phe-OH by Leu398-CPD-Y relative to CPD-Y, is increased to

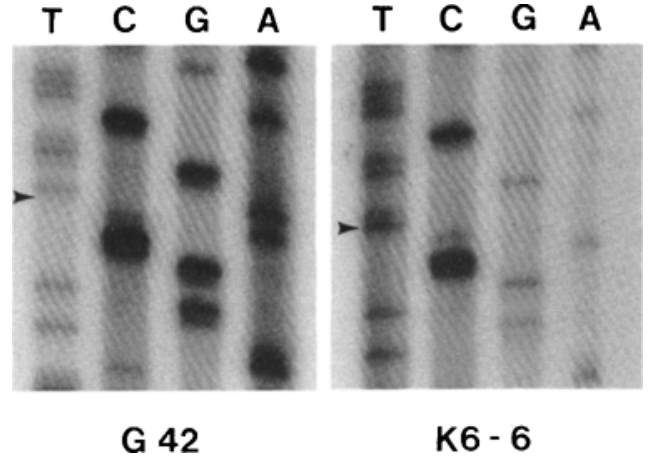

Figure 6. Comparison of mutant and wild type sequences surrounding the codon 398 . The autoradiographs of two $5 \%$ polyacrylamide gels show chain-termination reactions using the universal sequencing primer on G42 and K6-6 templates. The arrows indicate the appearance of $\mathrm{T}$ in the TTG codon for leucine.

the same extent. Thus, it appears that only the specificity with respect to the $P_{1}^{\prime}$ position of both ester and peptide substrates is affected by the Met to Leu mutation and this is consistent with Met-398 being located in the $S_{1}$ binding site.

Introduction of bulky groups on Met-398 by chemical modification, e.g. the phenacyl sulfonium group, causes a drastic reduction in $\mathrm{k}_{\text {cat }} / \mathrm{K}_{\mathrm{m}}$ for the hydrolysis of substrates with bulky groups in the $P_{1}^{\prime}$ position (4). In comparison, the effects of converting Met-398 to the corresponding methionyl sulfoxide residue, thus introducing only a single oxygen atom, were much less drastic (3). It was therefore no surprise that Leu-398-CPD-Y would exhibit enzymatic properties that only deviated slightly from those of CPD-Y. The tighter binding to Leu-398CPD-Y of substrates with bulky and hydrophobic $\mathrm{P}_{1}^{\prime}$ groups (as seen in Table II) is in accordance with the leucyl side-chain being slightly smaller and more hydrophobic (15) than the methionyl side-chain.

Earlier studies have shown that oxydation of Met-398 to methionyl sulfoxide reduces the thermostability of CPD-Y (3). In a similar experiment Leu-398-CPD-Y was inactivated at $55^{\circ} \mathrm{C}$ in an apparent first order reaction with the rate constant of $0.058 \mathrm{~min}^{-1}$ as compared 
J.R. WINTHER et al.: Mutagenesis on carboxypeptidase $Y$

Table I.

Hydrolysis of FA-peptide and FA-ester substrates with CPD-Y and Leu-398-CPD-Y

\begin{tabular}{|c|c|c|c|c|}
\hline Substrate & Enzyme & $k_{c a t}$ & $\mathrm{~K}_{\mathrm{m}}$ & $\mathbf{k}_{\text {cal }} / \mathbf{K}_{\mathrm{m}}$ \\
\hline \multirow[t]{2}{*}{ FA-Phe-Gly-OH } & CPD-Y & 5800 & 5.4 & 1100 \\
\hline & Leu-398-CPD-Y & 6200 & 17 & 360 \\
\hline \multirow[t]{2}{*}{ FA-Phe-Ala-OH } & CPD-Y & 9700 & 0.14 & 61000 \\
\hline & Leu-398-CPD-Y & 5800 & 0.33 & 18000 \\
\hline \multirow[t]{2}{*}{ FA-Phe-Val-OH } & CPD-Y & 6500 & 0.047 & 140000 \\
\hline & Leu-398-CPD-Y & 1700 & 0.045 & 38000 \\
\hline \multirow[t]{2}{*}{ FA-Phe-Leu-OH } & CPD-Y & 4900 & 0.021 & 230000 \\
\hline & Leu-398-CPD-Y & 1600 & 0.015 & 110000 \\
\hline \multirow[t]{2}{*}{ FA-Phe-Phe-OH } & CPD-Y & 6200 & 0.12 & 52000 \\
\hline & Leu-398-CPD-Y & 3200 & 0.05 & 62000 \\
\hline \multirow[t]{2}{*}{ FA-Val-Phe-OH } & CPD-Y & 660 & 0.063 & 11000 \\
\hline & Leu-398-CPD-Y & 430 & 0.027 & 16000 \\
\hline \multirow[t]{2}{*}{ FA-Ala-Phe-OH } & CPD-Y & 16000 & 1.20 & 13000 \\
\hline & Leu-398-CPD-Y & 4700 & 0.25 & 19000 \\
\hline \multirow[t]{2}{*}{ FA-Phe-OEt } & CPD-Y & 11000 & 0.059 & 190000 \\
\hline & Leu-398-CPD-Y & 8000 & 0.063 & 130000 \\
\hline \multirow[t]{2}{*}{ FA-Ala- OEt } & CPD-Y & 8000 & 0.8 & 10000 \\
\hline & Leu-398-CPD-Y & 9100 & 1.4 & 6700 \\
\hline \multirow[t]{2}{*}{ FA-Ala-O'Bu } & CPD-Y & 1100 & 4.5 & 250 \\
\hline & Leu-398-CPD-Y & 340 & 1.8 & 190 \\
\hline \multirow[t]{2}{*}{ FA-Ala-OBzl } & CPD-Y & 9100 & 0.054 & 170000 \\
\hline & Leu-398-CPD-Y & 6400 & $<0.01$ & $>600000$ \\
\hline
\end{tabular}

Assay conditions are described in section 2.2.6.

To ensure that the enzyme coded by the cloned $P R C 1$ gene was not significantly different from CPD-Y previously isolated from Danish bakers yeast the pTSY3-coded wild type enzyme was also purified and subjected to the same investigations as described for Leu-398-CPD-Y. In kinetic studies the differences between the two wild type enzymes did not exceed $10 \%$.

with $0.019 \mathrm{~min}^{-1}$ for the unmodified enzyme and $0.039 \mathrm{~min}^{-1}$ for the metionyl sulfoxide derivative. The adverse effect of even these minute changes at the Met-398 position on the stability indicates that this residue must be important for maintenance of the tertiary structure of CPD-Y.

The present data show that site-directed mutagenesis can be applied to refine the information about substrate-enzyme interactions obtained by specific chemical modifications of amino acid side-chains located in the binding sites. This approach does not require previous knowledge of the three-dimensional structure but it is desirable that the enzyme has a broad specificity such that the use of various substrates can aid the evaluation of the results. This renders the proteolytic enzymes particularly suitable, especially those exopeptidases that have a low degree of specificity and for which a large number of substrates are available.

The fact that substitution of Met-398 in CPD$Y$ for a leucyl residue affects the specificity of the enzyme with respect to the $P_{1}^{\prime}$ position 
J.R. WINTHER et al.: Mutagenesis on carboxypeptidase $\mathrm{Y}$

Table II.

The influence of the $P_{1}^{\prime}$ position on $K_{m}$.

\begin{tabular}{lc}
\hline \multirow{2}{*}{ Substrate } & $\mathrm{K}_{\mathrm{m}}($ Leu-398-CPD-Y) \\
\cline { 2 - 2 } & $\mathrm{K}_{\mathrm{m}}(\mathrm{CPD}-\mathrm{Y})$ \\
\hline FA-Phe-Gly-OH & 3.2 \\
FA-Phe-Ala-OH & 2.4 \\
FA-Phe-Val-OH & 0.96 \\
FA-Phe-Leu-OH & 0.71 \\
FA-Phe-Phe-OH & 0.43 \\
\hline
\end{tabular}

The ratio between $K_{m}$ of Leu-398-CPD-Y and $K_{m}$ of CPD-Y for various residues in the $P_{1}^{\prime}$ position as calculated from Table I.

implies that more drastic mutations at position 398 and neighbouring positions may be performed with the effect of altering the specificity of the enzyme in a predictable fashion, creating enzymes of potential biotechnological interest.

\section{ACKNOWLEDGEMENTS}

Dr. TOM STEvens, Institute of Molecular Biology, University of Oregon, USA, has, with his donation of the pTSY3 plasmid, the S. cerevisiae strain, SEY 2202, and the complete DNA sequence of $P R C 1$, been of invaluable help to the present work. Professor MARTIN OTTESEN is thanked for stimulating discussions and encouragement during this work and for critical reading of the manuscript. Drs. STEEN Holmberg and Jens G. Litske Petersen, Department of Physiology, Carlsberg Laboratory are gratefully acknowledged for stimulating discussions and valuable suggestions concerning molecular cloning experiments and for critical revision of the manuscript. Finally, Dr. IB SVENDSEN and Ms. IRENE SIMONSEN are acknowledged, respectively, for amino acid sequence determination and excellent technical assistance.

\section{REFERENCES}

1. Birnboim, H. C. \& J. Doly: A rapid alkaline extraction procedure for screening recombinant plasmid DNA. Nucl. Acids Res. 7, 1513-1523 (1979)

2. BREDDAM, $\mathbf{K}$ \& I. SVENDSEN: Identification of methionyl and cysteinyl residues in the substrate binding site of carboxypeptidase Y. Carlsberg Res. Commun. 49, 639-645 (1984)

3. BREDDAM, K.: Modification of amino acid residues in the $S_{1}^{\prime}$ binding site of carboxypeptidase Y. Carlsberg Res. Commun. 49, 627-638 (1984)

4. Breddam, K.: Chemically modified carboxypeptidase $Y$ with increased amidase activity. Carlsberg Res. Commun. 49, 535-554 (1984)

5. BREDDAM, K.: Modification of a single sulfhydryl group of carboxypeptidase $\mathrm{Y}$ with mercurials. Influence on enzyme specificity. Carlsberg Res. Commun. 48, 9-19 (1983)

6. Botstein, D., S. C. Falco, S. E. Stewart, M. Brennan, S. Scherer, D. T. StinchComb, K. STRUHL \& R. W. Davis: Sterile host yeasts (SHY): A eukaryotic system of biological containment for recombinant DNA experiments. Gene 8, 17-24 (1979)

7. Denhardt, D. T.: A membrane filter technique for the detection of complementary DNA. Biochem. Biophys. Res. Commun. 23, 641-644 (1966)

8. Dubois, M., K. A. Gilles, J. K. Hamilton, P. A. REBERS \& F. SMITH: Colorimetric method for determination of sugar and related substances. Anal. Chem. 38, 350-356 (1956)

9. Estell, D., T. P. Graycar \& J. A. Wells: Engineering an enzyme by site-directed mutagenesis to be resistant to chemical oxidation. J. Biol. Chem. 260, 6518-6521 (1985)

10. Gillam, S. \& M. Smith: Site-specific mutagenesis using synthetic oligodeoxyribonucleotide primers: 1. Optimum conditions and minimum oligodeoxyribonucleotide length. Gene 8, $81-97$ (1979)

11. Holmes, D. S. \& M. Quigley: A rapid boiling method for the preparation of bacterial plasmids. Anal. Biochem. 114, 193-197 (1981)

12. Ito, H., Y. FukUda, K. Murata \& A. Kimura: Transformation of intact yeast cells treated with alkali cations. J. Bacteriol. 153, 163-168 (1983)

13. Johansen, J. T., K. Breddam \& M. OTtesen: Isolation of carboxypeptidase $\mathrm{Y}$ by affinity chromatography. Carlsberg Res. Commun. 41, 1-14 (1976)

14. Kramer W., K. Schughart \& H. J. Fritz: Directed mutagenesis of DNA cloned in filamentous phage: influence of hemimethylated GATC sites on marker recovery from restriction fragments. Nucl. Acids Res. 10, 6475-6485 (1982)

15. KYTE, J. \& R. F. DoOlitTLE: A simple method for 
displaying the hydropathic character of a protein. J. Mol. Biol. 157, 105-132 (1982)

16. LEDERBERG, E. M. \&S. N. COHEN: Transformation of Salmonella Typhimurium by plasmid deoxyribonucleic acid. J. Bacteriol. 119, 1072-1074 (1974)

17. Maniatis, T., E. F. FritsCh, J. SAmbrooK: Molecular cloning. A laboratory manual. Cold Spring Harbor Laboratory, New York (1982)

18. MaXam, M. A. \& W. GilberT: A new method for sequencing DNA. Proc. Natl. Acad. Sci. USA 74, 560-564 (1977)

19. Messing, J.: A multi-purpose cloning system based on the single-stranded DNA bacteriophage M13. Recombinant DNA Tech. Bull., NIH publication No. 79-99, 2, 43-48 (1979)

20. Messing, J.: New M13-vectors for cloning. Methods Enzymol. 101, 20-78 (1983)

21. Messing J. \& J. Vieira: A new pair of M13 vectors for selecting either DNA strand of double-digest restriction fragments. Gene 19, 269-276 (1982)

22. Murray, N. E., W. J. Brammar \& K. Murray: Lambdoid phages that simplify recovery of in vitro recombinants. Mol. Gen. Genet. 150, 53-61 (1977)

23. Petersen, J. G. L., M. C. Kielland-Brandt, $\mathbf{S}$. HOLMBERG \& T. NiLSSON-TILLGREN: Mutational analysis of isoleucine-valine biosynthesis in Sac- charomyces cerevisiae. Mapping of $i l v 2$ and ilv 5 . Carlsberg Res. Commun. 48, 21-34 (1983)

24. SANGER, F., S. NiCKLEN \& A. R. COULSON: DNA sequencing with chain-terminating inhibitors. Proc. Natl. Acad. Sci. USA 74, 5463-5467 (1977)

25. Schechter, I. \& A. Berger: On the size of the active site of proteases. I. Papain. Biochem. Biophys. Res. Commun. 27, 157-167 (1967)

26. Weber, K., J. R. Pringle \& M. Osborn: Measurement of molecular weights by electrophoresis on SDS-acrylamide gel. Methods Enzymol. C. XXVI, 3-27 (1972)

27. Wilkinson, A. J., A. R. Fersht, D. M. Blow, P. CARTER \& G. WINTER: A large increase in enzymesubstrate affinity by protein engineering. Nature 307, 187-188 (1984)

28. Winter, G., A. R. Fersht, A. J. Wilkinson, M. ZOLLER \& M. SMITH: Redesigning enzyme structure by site-directed mutagenesis: tyrosyl tRNA synthetase and ATP binding. Nature 299, 756-758 (1982)

29. YANG, R. C. A., J. LIS \& R. WU: Elution of DNA from agarose gels after electrophoresis. Methods Enzymol. 68, 179-182 (1979)

30. ZOLLER, M. \& M. SMITH: Oligonucleotide-directed mutagenesis of DNA fragments cloned into M13 vectors. Methods Enzymol. 100, 468-500 (1983)

Accepted by S.O. ANDERSEN 